\title{
Planning of Africa's land/water future: Hard or soft landing?
}

\author{
This article belongs to Ambio's 50th Anniversary Collection. Theme: Solutions-oriented \\ research
}

Malin Falkenmark

Published online: 14 March 2021

In the 1970 s and 1980s, widespread African poverty, famines and rapid population growth generated an urgent need for solution-oriented water research in order to get a basic idea of the water availability and degree of water scarcity of the vast semiarid drylands (Falkenmark 2018), and possible implications for African social-economic development research was focusing on the absence of water in the semi-arid soils, rather than on the water that had in fact infiltrated (Falkenmark and Rockström 2015).

My paper in Ambio (1989) study revealed that water scarcity was threatening two thirds of the African population, with large regional differences. The paper identified increasing problems both in terms of the water required to secure self-sufficient crop production, and in terms of the growing number of people competing for each unit of available water, i.e. as supplied to the country from the water cycle. This meant that from a medium-term perspective, water would not be readily available to support improved quality of life for the growing sub-Saharan population (Falkenmark 2018). Increased awareness among African leaders of water cycle realities stood out as crucial for social-economic development under severe water scarcity.

\section{UNPACKING THE PROBLEM: AFRICAN BLUE WATER SCARCITY BY YEAR 2050}

During following years, the water crowding scale from the Ambio 1989 paper was made two-dimensional by adding a scale of water stress, expressed as the amount of water already in use (\% of water availability) (Falkenmark 2018). The resulting two-dimensional diagram (Fig. 1) would demonstrate two simultaneous pressures on the blue water availability in a country: in terms of how many people are competing for the locally accessible water, and how much is already in use. In this diagram, actual water use would appear as a point, and its development over time as a line. An historical overview of a large number of such country lines (so called archetypes of water scarcity), were recently identified by Kummu et al. (2016), showing how water withdrawal had continuously been increasing since 1900 AD.

The future blue water shortage expected in African countries by 2050 is shown in Fig. 2, in terms of water availability projections (m3 per person per year after attention paid to both population growth and climate change effects). Brown colours show countries with high water stress (less than $1000 \mathrm{~m} 3$ per person per year), showing chronic shortage for much of the vast semi-arid region in sub-Saharan Africa. Dark brown colour shows those with extreme stress (less than $500 \mathrm{~m} 3$ per per person per year) and more than $40 \%$ of the availability already in use. The particularly exposed sub-Saharan African regions includes several large urban water hubs. In the east the Nile River has its sources, in the south are the sources of a quartet of transnational rivers, supplying a multitude of downstream countries with the water on which their socioeconomic future largely depends.

\section{THE UPTAKE OF A CONCEPT: GREEN WATER FOR BIOMASS PRODUCTION}

In contrast, the World Commission on Environment and Development, (so-called Brundtland Commission) in its report 1987 gave an impression that there is water everywhere and the basic problem is to keep it clean - which may be true in some ways, especially for the temperate North, but highly misleading as a globally valid message. 


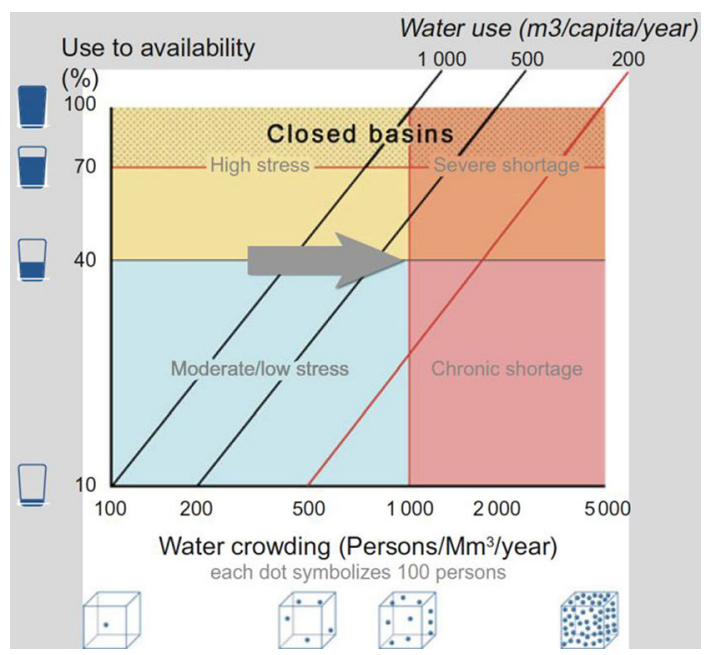

Fig. 1 Falkenmark water scarcity matrix (double-logarithmic scales). Arrow shows effect of population growth. From Falkenmark (2018)

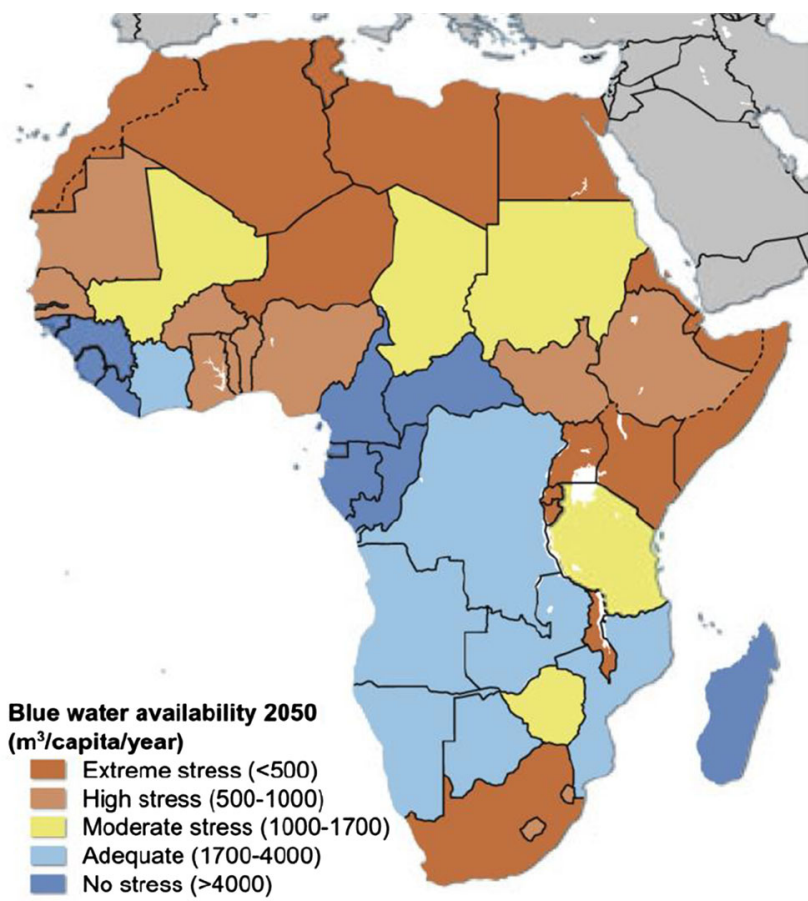

Fig. 2 Country level blue water scarcity by 2050. Shows blue water availability in m3/p yr. Data from Schuol et al. 2008. From Falkenmark (2018)

At this time, land use remained seen as a two-dimensional activity only, distributed over different land cover types. Thus, little had in fact changed since the United Nations Water Conference in Mar del Plata 1977, where water was discussed primarily in terms of technical water supply issues, and water for agricultural production therefore only in terms of irrigation water (Schulze 2006).

Thus, in the late 1980s, as earlier indicated, water for food remained poorly conceptualized. This led to Swedish members of International Water Resources Association (IWRA), at two subsequent IWRA Conferences, proposing international "IWRA Statements on Water, Environment and Development", recommending attention payed to the role of water for social-economic development on the Earth (Rockström et al. 2014).

To follow up the IWRA initiative, Sweden, in a FAOmeeting in Rome in January 1993, proposed the new concept "green water" for water in the soil. In the Swedish International Hydrological Decade/Programme research, soil water issues had been increasingly in focus since the late 1960s, driven not least by a strong interest in the development of semiarid countries. This generated large interest in green water research (Rockström 1996; Falkenmark 2020), including a world map showed at the Stockholm Water symposium 2000, displaying the relative size of blue and green water flows in global agricultural production. Overall, the research indicated that green water is in fact the water that dominates global food production. In 2007, in the massive publication "Water for food, Water for life" from the International Water Management Institute (IWMI) a whole chapter was devoted to long-term development of rain fed agriculture in dry climate regions.

\section{FOOD WATER AVAILABILITY DETERMINES WATER USE OPTIONS}

In 2010, a principal country-by-country projection of green as opposed to blue water requirement for food production by 2050 (Rockström et al. 2011) clarified the relative distribution between regions in the world, showing that: (a) there is enough green water available for food selfsufficiency; (b) there is insufficient green water, but enough blue water to allow irrigation; and (c) blue water availability would remain too limited to allow for self-sufficiency by additional irrigation, and that food thus would have to be imported; a very relevant fact for a poor country's long term economic planning. In principle, food import would then have to be secured through cost coverage, secured by economic development. In water scarce Africa, this might be secured for instance by developing a low cost industrial sector, supporting social-economic development, based on regionally available natural resources.

This clarifies the problematics of sub-Sahara's water scarcity, and water allocation ability to meet water requirements of competing social sectors (Falkenmark $2018,2020)$. In the water allocation in the 1990 s, the Israeli expert, Hillel Shuval proposed a combined standard water supply of $200 \mathrm{~m}^{3}$ per person per year for municipalities and industry in an industrialized dry climate country. In the water resources management of NE China's large water 
scarce rivers (Hai, Yellow, Huai Rivers), a certain percent of the river flow has to be reserved for environmental flow downstream. In these rivers, the consequence would be that irrigation may be considered only when and where more than $500 \mathrm{~m}^{3}$ per person per year is available for further allocation.

\section{AMBIO ARTICLE IMPLICATIONS}

It is evident from this article that the 20 years since its publication in Ambio in 1989 have seen an impressive switch in gear from the under developed understanding of water among decision makers that was still prevalent in the 1970s and early 1980s, that may at least partly have been sparked by the Ambio paper. The late 1980s were also the years for preparing for the UN Rio-Conference on the Human Environment 1992 which gave the issues further traction.

In the late 1980s, the World Bank deepened their interest in water scarcity on the water resources development arena, for instance by inviting the author to interact with the Bank's environmental and water supply expertise. In the early 1990s, a multinational expert meeting was organized in Victoria Falls in Africa, highlighting in particular the implications of the ongoing population growth on the region's water conditions, later to be followed by a number of regional SADC meetings. Considerable personal interaction took also place, where Professor Roland Schulze had a leading role for unpacking the large, misunderstood hydro-climatic differences between the hydrological understanding of the Northern temperate zone, and the hydroclimatic aridity and other types of tropical reality of the dry climate environment on the African continent (Schulze 2006). At the Swedish national level, the Intergovernmental Hydrological Programme (IHP) continued to keep research active, and an interdisciplinary water school was introduced at Linköping University.

During the following two decades, multiple institutional transformations took place in Sweden, starting with the Royal Swedish Academy of Sciences initiative of an annual international Stockholm Water Symposium and international Stockholm Water Prize. Some years later, a formal Stockholm International Water Institute (SIWI) was formed, in charge of organizing annual World Water Weeks in Stockholm-today attracting almost 4000 water experts every year. In 2016, the World Water Week issued an international Call for an African Green Water Agricultural Revolution (Falkenmark et al. 2009). As a follow-up, SIWI is now working with the African Sustainable Development Center in Kigale, and has started a SIWI project of "Transforming Africa through Accelerating
Rainfed Agricultural Revolution", giving particular emphasis on creating a shift in mindsets and providing cost coverage of water tanks, and rainwater harvesting, aiming at supplementary irrigation of sub-Saharan drylands.

In the two decades following the Ambio 1989 paper, Stockholm University was active in developing considerable water activities, starting with green water research, water seminars and publications (Rockström 1996). Four generations of scholars are now active in the Stockholm Resilience Centre, including the Ambio article author.

\section{FINAL COMMENTS}

For Africa, with a population foreseen to multiply several times already in this century (Falkenmark 2018), the original issue raised in the 1989 paper- "the massive water scarcity threatening Africa, why isn't it being addressed?"-is clearly still valid. In the long term perspective a relevant question for the planning of Africa's land/water future might be "hard or soft landing" (Falkenmark and Molden 2008). There is an urgent need to identify expected water demand constraints and hidden future water scarcity challenges for the sub-Saharan African region.

Were the action items proposed in the 1989 paper in response to the accelerating water scarcity identified, actually implemented? Yes and no. As the account above shows, the concepts and ideas have led to major changes in policy as well as practice, but the direct uptake in practice in the African countries was slow and hampered particularly by rapid urbanization, a delayed lack of water planning, and slow change in mind-sets.

\section{REFERENCES}

Falkenmark, M. 2018. Shift in water thinking crucial for sub-saharan Africa's future. In Assessing global water megatrends, ed. A.K. Biswas, C. Tortajada, and P. Rohner, 147-177. New York: Springer.

Falkenmark, M. 2020. Water resilience and human life support-global outlook for the next half century. International Journal of Water Resources Development 36: 377-396.

Falkenmark, M., and D. Molden. 2008. Wake up to realities of river basin closure. International Journal of Water Resources Development 24: 201-215.

Falkenmark, M., and J. Rockström. 2015. Double water blindness delaying sub-Saharan green revolution. Water for Development: Charting a Water Wise Path, SIWI Report 35: 64-68.

Falkenmark, M., J. Rockström, and L. Karlberg. 2009. Present and future water requirements for feeding humanity. Food Security 1: 59-69.

Kummu, M., J. Guillaume, H. De Moel, S. Eisner, M. Flörke, M. Porkka, S. Siebert, T. Veldkamp, et al. 2016. The world's road to 
water scarcity. Scientific Reports 6: 38495. https://doi.org/10. 1038/srep38495.

Rockström, J. 1996. Moving towards a new water resources agenda. In Proceedings, Sixth Stockholm Water Symposium.

Rockström, J., L. Karlberg, and M. Falkenmark. 2011. Global food production in a water-constrained world: Exploring 'green'and 'blue'challenges and solutions. In Water resourcs planning and management, ed. R.Q. Grafton and K. Hussey, 131-151. Cambridge: Cambridge University Press.

Rockström, J., M. Falkenmark, C. Folke, M. Lannerstad, J. Barron, E. Enfors, L. Gordon, J. Heinke, et al. 2014. Water resilience for human prosperity. Cambridge: Cambridge University Press.

Schulze, R.E. 2006. Some foci of integrated water resources management in the "South" which are oft-forgotten by the
"North": A perspective from southern Africa. Integrated Assessment of Water Resources and Global Change, 269-294. New York: Springer.

Publisher's Note Springer Nature remains neutral with regard to jurisdictional claims in published maps and institutional affiliations.

Malin Falkenmark ( $\square)$

Address: Stockholm Resilience Centre, Stockholm University, Kräftriket 2B, 10691 Stockholm, Sweden.

e-mail: malin.falkenmark@su.se 